Article

\title{
Smart Integrated Renewable Energy Systems (SIRES): A Novel Approach for Sustainable Development
}

\author{
Zeel Maheshwari ${ }^{1, *}$ and Rama Ramakumar ${ }^{2}$ \\ 1 Graduate Research Associate, Engineering Energy Laboratory, Oklahoma State University, Stillwater, \\ OK 74075, USA \\ 2 Director, Engineering Energy Laboratory, Oklahoma State University, Stillwater, OK 74075, USA; \\ rama.ramakumar@okstate.edu \\ * Correspondence: zeel.maheshwari@okstate.edu; Tel.: +1-585-754-6344
}

Received: 23 June 2017; Accepted: 3 August 2017; Published: 4 August 2017

\begin{abstract}
Technical and economic aspects of the viability of SIRES (Smart Integrated Renewable Energy Systems) for sustainable development of remote and rural areas of the world are discussed. The hallmark of the proposed SIRES is the smart utilization of several renewable resources in an integrated fashion and matching of resources and needs a priori with the ultimate goal of "energization", not just "electrification". Historical background leading to this approach is succinctly presented along with a comprehensive schematic diagram. Modeling of various components and their collective use in optimizing SIRES with the aid of genetic algorithm are presented using a typical hypothetical example. SIRES is also compared with various approaches for rural development based on Annualized Cost of System (ACS) and installation costs. Implementation of SIRES will lead to overall sustainable development of rural communities.
\end{abstract}

Keywords: energization; integrated renewable energy systems; rural smart communities; sustainable development; genetic algorithm

\section{Introduction}

With the ever growing population of the world with increasing expectations and the associated environmental concerns, it is not prudent to rely solely on fossil fuels in the long-term. A historic agreement took place between 195 countries in the 2015 United Nations Climate Change Conference held in Paris, France. These countries agreed to hold the increase in the global average temperature to well below $2{ }^{\circ} \mathrm{C}$ above pre-industrial levels and also make efforts to limit the temperature increase to $1.5^{\circ} \mathrm{C}$. To achieve this goal, the key is reducing the dependence on fossil fuels and cutting greenhouse emissions. Global environmental concerns combined with sustained development in renewable energy technologies have exponentially increased the entry of renewable energy. Significant cost reductions over the past few decades have made a number of renewable energy resources competitive with fossil fuels in various applications [1].

According to the International Energy Agency (IEA), 2.5 billion people rely on fuelwood, charcoal, agriculture waste and animal dung to meet their needs for cooking. However, use of these resources in an unsustainable manner is leading to serious adverse consequences for health and environment. About 1.3 million people (mostly women and children) die prematurely solely because of indoor pollution caused by burning biomass [2]. Moreover people living in these areas spend about $2.6 \mathrm{~h}$ and trek $4.8 \mathrm{~km}$ per day per family to collect about $10 \mathrm{~kg}$ of firewood [3]. According to the World Health Organization (WHO), about 750 million people lack access to safe water. On an average, $1.5 \mathrm{~h}$ are spent and $1.7 \mathrm{~km}$ is covered per day per household to fulfill a modest domestic water consumption of $17 \mathrm{~L}$ per day which is significantly below the global average [4]. Therefore fetching water and fuelwood for domestic consumption utilizes a great deal of human energy, especially for women who carry out 
majority of this unpaid work. This point has been clearly addressed in the 2016 annual Gates Letter [5]. According to the IEA's World Energy Outlook, approximately 1.2 billion people in the world have no access to electricity and $85 \%$ of them live in rural areas [6]. Table 1 gives a summary of percentage of people living in rural areas who are lacking basic needs.

Table 1. Percentage of Energy Deprived Rural Areas [2,4,6].

\begin{tabular}{ccc}
\hline Basic Needs & Population Without Access (in World) & Percentage Living in Rural Areas \\
\hline Safe Water & 750 million & $90 \%$ \\
Proper stove for cooking & 2.5 billion & $85 \%$ \\
Electricity & 1.3 billion & $85 \%$ \\
\hline
\end{tabular}

In September 2000, the largest gathering of world leaders in history, called the millennium summit, adopted the UN Millennium Declaration. It required the nations of the world to commit to a new global partnership to reduce extreme poverty and set a series of time-bound targets. These well defined goals have now become known as the Millennium Development Goals. The Millennium Development Goals (MDGs) are the world's first time-bound and quantified targets for addressing extreme poverty in its many dimensions while promoting gender equality, education, and environmental sustainability. They are also basic human rights: the rights of each person on the planet to health, education, shelter, and security [7].

As a follow up, another set of goals called Sustainable Development Goals (SDGs) were built on the successes of the MDGs with a vision of fulfilling these goals while safeguarding the environment by 2030. On 25 September 2015, SDGs were formed as a ambitious set of goals from the discussions at UN Sustainable Development Summit 2015. The SDGs were recorded in a document entitled "Transforming our world: Toward the Agenda 2030 for Sustainable Development". Goal number 7 of this agenda signifies the need to ensure access to affordable, reliable and sustainable energy for all. Additional set of targets in SDGs included climate change, economic inequality, innovation, sustainable consumption, peace and justice, among other priorities. The goals are interconnected-often the key to success of one will involve tackling issues more commonly associated with another [8]. These apply in particular to rural areas of sub-Saharan Africa, Latin America, the Middle east, North Africa and parts of Asia. Energy in various forms is required for growth and development in rural areas. Renewable resources are an indispensable alternative for fossil fuels to provide sustainable energy for development. Various steps have to be taken to improve the basic living environment and meet the energy and other necessities of these rural areas in a sustainable manner $[9,10]$.

\subsection{Literature Review}

Extension of grid, commonly known as rural electrification was the earliest solution proposed to electrify rural areas. Extending national grids is an infeasible and ineffective option in many countries because of the high cost of grid extension and low load factors. A study of the World Bank on rural electrification programs estimated the average cost of grid extension per km between $\$ 8000$ and $\$ 10,000$ rising to around $\$ 22,000$ in difficult terrains [11]. Electricity Home Systems (EHS) are small power systems that are designed to power individual homes or small buildings and provide an easily accessible, relatively inexpensive, and simple to maintain solution. Since houses in rural area are dispersed, it is an ideal setting for this approach. Pico Photovoltaic Systems (PPS), Solar Home Systems (SHS), or Wind Home Systems (WHS) offer solutions for providing electricity in isolated places (See [1]). Recently, significant research effort has been devoted to microgrids for the development of rural areas. Several microgrids have been installed with ratings ranging from as little as $1 \mathrm{~kW}$ to as large as a few hundred kilowatts. Microgrids can either be AC or DC. These microgrids fulfill a range of needs from lighting, communication to commercial purposes. Seven such cases installed in India, Malaysia and Haiti have been studied in depth [12]. 
In the past decades, several approaches were discussed to exploit locally available renewable energy resources. One of the method was a step-by-step approach for adoption of renewable technologies at rural level [13]. This approach consists of an electric system and water supply system constituting an energy center. The energy center was further revised and enhanced into a system called Integrated Renewable Energy System (IRES) for the development of rural areas [14]. IRES can be described as a system that harnesses two or more forms of locally available renewable energy resources to supply a variety of energy and other needs of a remote rural area in a most efficient, cost effective and practical manner, with the ultimate goal of coalescing the benefits at the user end. Another approach introduced recently for rural development is "IEEE Smart Village". It was earlier known as "Community Solutions Initiative (CSI)". In 2009, CSI was launched to address the situation of rural population who have no access to electricity. CSI's technical model consists of a standardized charging station called SunBlazer. It is a mobile platform with up to 80 portable battery packs (PBKs) and home lighting kits per station. IEEE Smart Village has been serving numerous countries such as Benin, Cameroon, India, Kenya, Malawi, Namibia, etc. [15,16].

Koutroulis et al. have proposed a methodology for optimal sizing of stand-alone PV/Wind systems using Genetic Algorithms (GA) [17]. The suggested approach has been applied to design a power generation system for a residential household. A Hybrid Energy System (HES) was developed by Ashok to provide electrification of the rural villages in Western Ghats (Kerala), India [18]. The combination of micro-hydro and wind systems was optimized by minimizing life-cycle cost. An optimal sizing method for stand-alone solar-wind system using genetic algorithm was proposed by Yang et al. [19]. Minimum Annualized Cost of System (ACS) and required Loss of Power supply probability (LPSP) were the two objective functions considered. Kanase-Patil et al. formulated and optimized IRES for different available options for a cluster of villages to supply electricity. Reliability worth, Cost of Energy (COE), effect of sensitive prices of biomass fuel have also been studied [20]. A decentralized, off-grid electrification using renewable energy technologies for rural Tanzania and Mozambique is recommended by Ahlborg [21]. This thesis also included an exhaustive list of barriers to rural electrification in sub-Saharan Africa, as perceived by power sector actors. A multi-objective optimization model is suggested by Agarwal et al. to optimally size grid independent solar-diesel-battery based hybrid system. The proposed model was applied to unelectrified remote village of India to minimize total life cycle cost of the system and minimize $\mathrm{CO}_{2}$ emissions from the system [22]. Ramoji et al. presented a Genetic Algorithm and Teaching Learning Based Optimization (GA and TLBO) to economically size PV-Wind hybrid energy system [23]. Ko et al. designed a multi-objective optimized hybrid energy system consisting of three types of renewable energy and six types of fossil fuels. The aim of the paper was to minimize Life Cycle Cost (LCC) while simultaneously maximizing the penetration of renewable energy and minimize annual Greenhouse Gas (GHG) emissions [24]. A study was carried out by Barman et al. in four districts of Assam, India to assess the technical functionality of Solar Home Lighting Systems (SHLS) [25].

\subsection{Scope and Structure of this Paper}

In the above literature review, earlier approaches such as Grid Extension, EHS, HES, Microgrids and IEEE Smart Village have been implemented to provide electricity in rural areas. However, very little attempts have been made to meet the basic necessities, such as, cooking, domestic and irrigation water. Therefore, an improved and a smarter version of IRES titled Smart Integrated Renewable Energy System (SIRES) is proposed to fill this gap. A broad comparison of various approaches to rural development is discussed comprehensively in [26]. Previously, optimization techniques such as genetic algorithm have been used to optimally size the components for only single output (electricity) systems. In this paper, GA has been used for a multi-output (biogas for cooking, water for domestic and irrigation use, electricity) systems. A notable complexity dealing with multi-resource multi-need system is that one resource will be used to fulfill various needs simultaneously. This requires additional energy management techniques, which have been embedded in SIRES. 
The significant contributions of this paper include:

- Introducing the concept of "Energization"

- Development of a genetic algorithm for optimal sizing to minimize cost and maximize reliability for SIRES (multi resource-multi need system)

- Collection of data for parameters, such as weather (insolation, wind speed, rainfall, humidity, temperature), domestic water consumption and electricity

- Comparison of cost (ACS, Net Present Cost (NPC) and installation cost) with existing methods, such as grid extension, microgrid (with and without diesel generator)

Section 2 details on the key differences between the terms Electrification and Energization. Components of SIRES and a generic schematic diagram is presented in Section 3. In Section 4, analysis and modeling details needed for the application of GA are presented. Section 5 discusses the results for optimal sizing of system components of SIRES and cost comparisons with other approaches for a hypothetical system. In Section 6, concluding remarks are succinctly presented.

\section{Electrification vs. Energization}

The concept of energization refers to the best use of energy in available resources to satisfy various needs. In energization, any one resource can be used to satisfy more than one need. The goal is to use all the resources to meet all the needs in the most efficient manner by matching the resources with the needs as appropriate in an integrated manner. Electrification converts all forms of energy resources to electrical form which is then used to satisfy various needs with no consideration to the overall efficiency of utilization. These terms are often mistaken to be analogous to each other, but in reality Electrification can be considered as a subset of Energization. Figure 1 depicts the vital differences between electrification and energization.

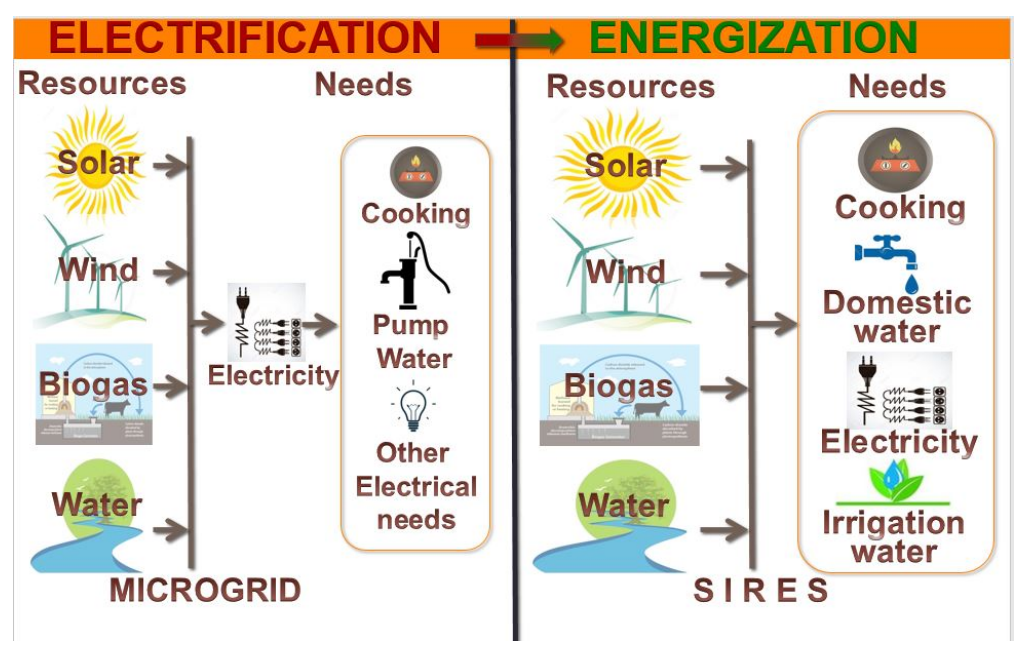

Figure 1. Electrification vs. Energization.

Microgrids, a version of Electrification, converts all the available resources into "Electricity". For instance, biogas is converted into electricity and then used for cooking. Another example is wind energy is used to produce electricity. The generated electricity is subsequently used to pump water. This process reduces the end-use efficiency. On the other hand, in SIRES, an example of energization, resources are directly utilized to fulfill basic needs as much as possible. In addition, these resources can be used generate electricity as and when required. For instance, biogas is directly used for cooking rather than converting into electricity and then using it for cooking. Similarly, water is pumped to overhead reservoir using solar and wind mechanical water pumps. 


\section{Smart Integrated Renewable Energy Systems (SIRES)}

This paper proposes the integrated use of several resources to meet various energy needs. Several previous attempts have employed multiple resources in a hybrid manner with electricity as the means to satisfy the needs. The uniqueness of the proposed approach is to consider the issue on a system level with different resources meeting different needs in an interchangeable manner as the situation warrants to maximize the overall energy use efficiency to improve economic, social and environmental aspects of the rural area.

SIRES primarily comprises of biogas digesters and stoves, wind-electric conversion systems, wind mechanical conversion systems, PV modules, PV-powered water pumps, pico hydro power plants, elevated water storage tanks, biogas powered generator, biogas powered water pump, batteries, fuel cells, converters and inverters. Fundamental needs of rural areas include potable and domestic water, irrigation water, medium grade thermal energy for cooking, low-grade thermal energy for heating, and electricity for lighting, communication, cold storage and educational purposes [26]. One possible schematic of SIRES harnessing multiple resources and supplying a variety of needs is shown in Figure 2 .

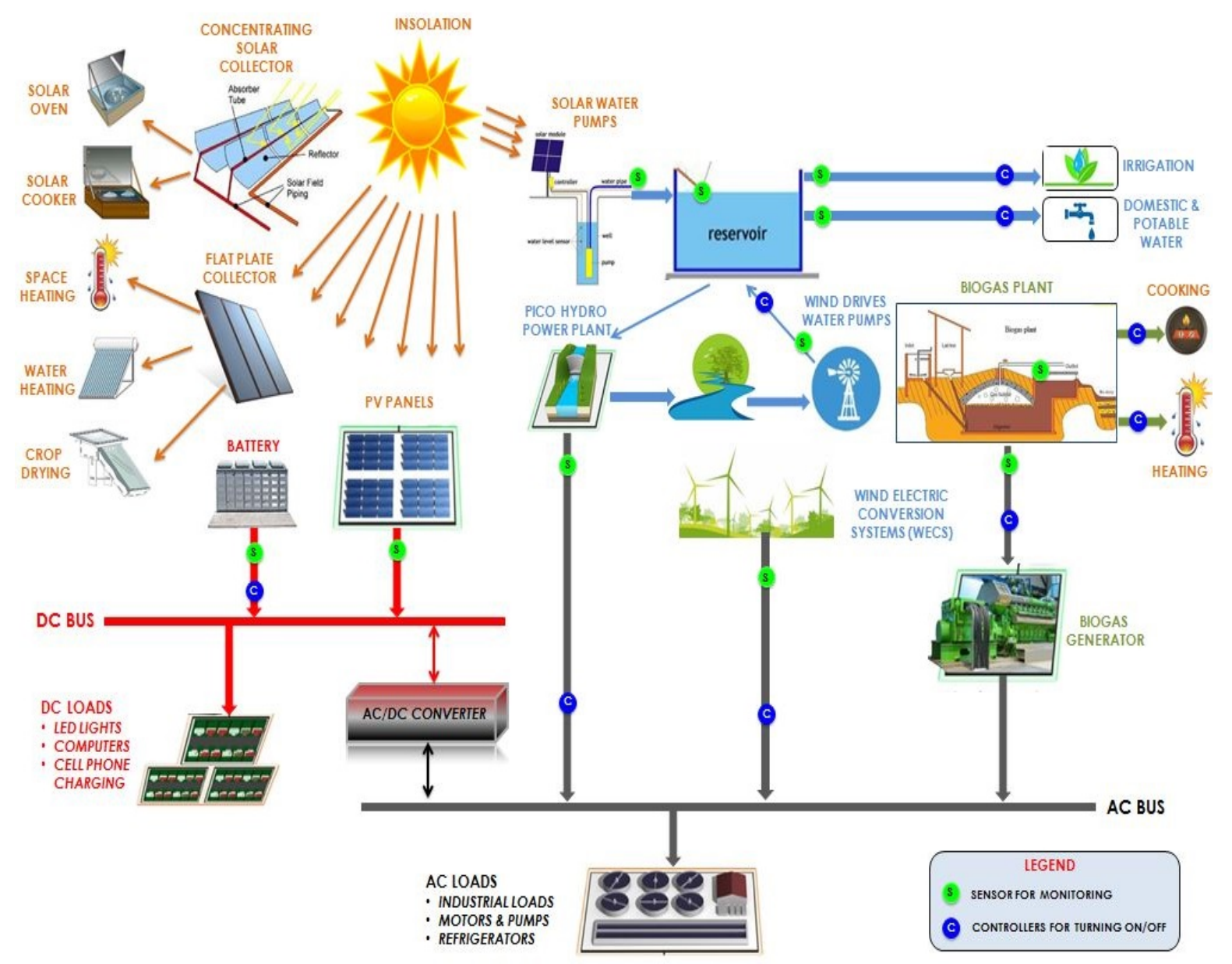

Figure 2. Generic schematic diagram of SIRES.

\subsection{Operation of SIRES}

Renewable resources such as biomass, solar radiation, wind and falling water are readily available in rural areas. These resources are inputs to SIRES. Biomass constitutes agriculture residues, livestock manure, dead trees remains, human wastes and other organic wastes. Collected biomass is digested anaerobically to produce biogas. Biogas is primarily used for cooking, which is the highest priority need 
for SIRES. Leftover biogas is used to generate electricity and pump water to overhead reservoir. Water from rivers, ponds and streams is pumped by using wind mechanical water pumps and PV powered water pumps into an overhead reservoir. It is used to fulfill demands of domestic and irrigation water needs of rural areas. Water remaining in the reservoir is utilized to generate electricity by employing a pico-hydro unit. Wind electric conversion systems and solar photovoltaic arrays utilizing insolation (incident solar radiation) are employed to generate electricity. Solar flat plate collectors can fulfill low-grade thermal demands of rural areas. Electricity generated is supplied to rural areas through two buses: AC bus and DC bus. AC bus supplies loads such as motors, pumps, industrial appliances and devices, refrigerator and so on. DC bus supplies loads such as communication and educational devices, thermoelectric cooler, cell phones chargers, computers and laptops, domestic and street LED lighting etc. Smart sensors are strategically placed at locations where availability of resources have to be monitored. Sensors will also be placed at locations where the status of system components should be monitored. Intelligent controllers will be used to turn on/off equipment. Data obtained from the sensors can be transmitted through a basic telemetry/cellular network for use in further research and improvement.

\subsection{What Is "Smart" about This Approach?}

- SIRES maximizes the impact by "energization" as compared to "electrification", which is not efficient and cost-effective for demands such as cooking, water pumping etc.

- Needs are prioritized based on necessities of daily life. For example, cooking would be on a higher priority when compared to electricity, and water for domestic purpose would be on a higher priority when compared to irrigation water

- Use of Genetic Algorithm (GA), which optimizes the operation of system components to minimize annualized cost of system and maximize reliability

- Operation and resiliency are enhanced by using smart sensors and intelligent controllers

\section{Analysis and Modeling}

Cost optimization of SIRES is carried out in steps as shown in Figure 3. In order to fulfill basic needs of a rural area, it is mandatory to determine the most appropriate technologies, equipments and facilities. For this purpose, the first stage is carried out to undertake an initial analysis of the given rural area. The objective of the second stage is to model system components, system reliability and annualized cost of system. In the final stage, objective functions are formulated and genetic algorithm is applied to optimize cost subject to specified reliability requirements. Each stage and the corresponding objectives are explained in the following subsections.

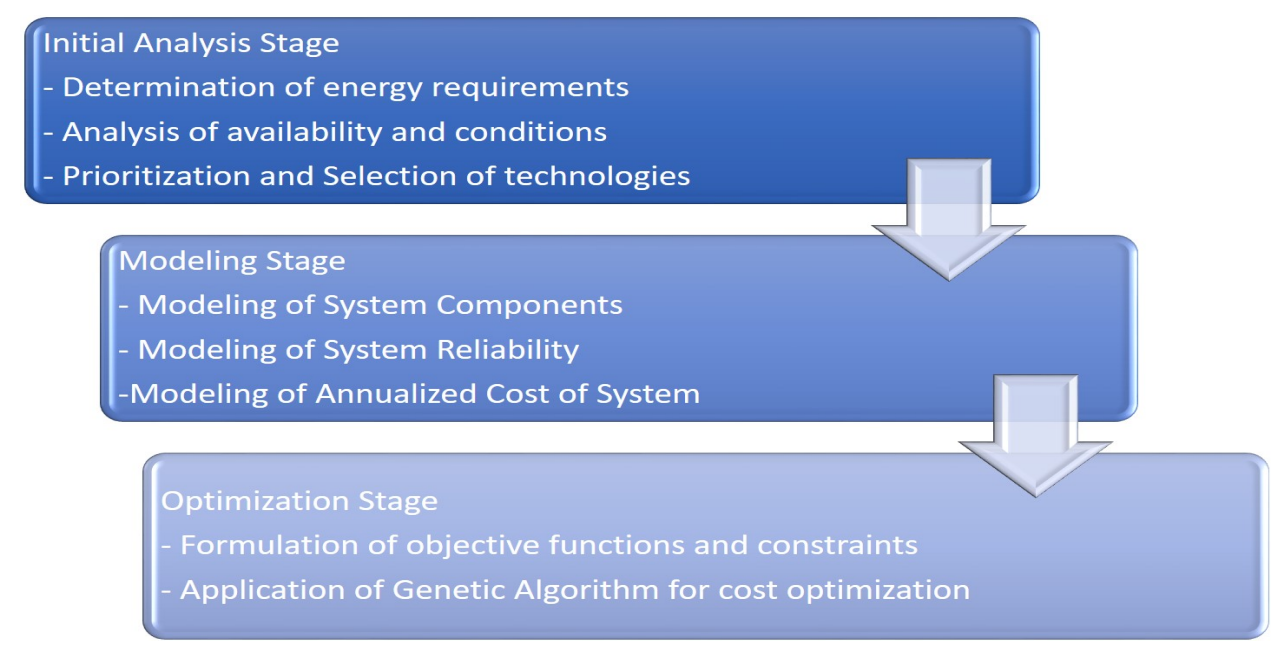

Figure 3. Procedural Steps for cost optimization of SIRES. 


\subsection{Initial Analysis}

A hypothetical rural area with a population of 700 in 120 households and 450 cattle is considered. It is assumed to be located at $36.1156^{\circ} \mathrm{N}, 97.0584^{\circ} \mathrm{W}$. Most of the people have agriculture as their basic occupation. 200 acres ( 80 hectares) is considered available for agriculture. The objective of initial analysis is to determine the energy requirements, analyze availability and conditions, followed by prioritization and selection of technologies.

\subsubsection{Determination of Energy Requirements}

Projecting energy requirements that reflect reality is rather difficult, especially for prospective consumers who have little or no experience with assessing energy requirements. A viable approach to assess demand is to survey households in adjoining, already electrified, areas or in a region with similar economic activities, demography etc. For this study, most of the energy requirement details have been gleaned from suitable references. Four basic needs-cooking, domestic water, electricity and irrigation water are considered. Biogas consists of methane (50-70\%), carbon-dioxide (30-50\%) and small traces of hydrogen sulphide and other gases. In this respect, the mixture of gases, with the exception of carbon-dioxide, is same as conventional cooking gas. Hence biogas is used for cooking in SIRES because it is the most effective, economic and efficient option. Every person requires about $0.34-0.42 \mathrm{~m}^{3}$ of biogas every day for cooking purpose [27]. Therefore for 700 people, about $238-294 \mathrm{~m}^{3}$ of biogas is needed every day for the rural area under consideration. Pattern of biogas consumption for cooking is decided empirically. Average level of water consumption per capita for domestic use in rural area is estimated to be $71.3 \mathrm{~L}$ [28]. Water used for drinking, showering, laundry, personal hygiene, house and yard cleaning and washing vessels is included in domestic water consumption. To assess the pattern of consumption of domestic water, water utility engineer at City of Stillwater was contacted. Hourly water consumption for one year is collected. Urban water usage is more compared to rural areas. Hence the water consumption is scaled by $2 / 3$ to match the average consumption per capita in rural area as mentioned earlier.

Making electrical load projections for people who have little or no experience is a difficult task. Therefore based on empirical knowledge and available literature, a list of appliances and their average usage every day is estimated. Table 2 shows basic electrical appliances required in the rural area with their usage hours and quantity for every household [29,30]. Due to high cost of electricity generation, it is very important to choose the most efficient appliances. The basis for all assumptions is the projected use of such appliances. Therefore for 120 households daily electrical energy needed varies from $300-360 \mathrm{kWh}$. Electricity for community purposes is assumed to be around $45-55 \mathrm{kWh}$. Hence the total electricity consumption for the rural area will vary from $345-415 \mathrm{kWh}$ per day.

Table 2. Estimated Electricity Demand per Household.

\begin{tabular}{ccccc}
\hline Appliance & Rating (W) & Quantity & Hours of Daily Usage & Total Energy Consumption (Wh)/day \\
\hline Bulbs & 15 & 4 & 5 & 300 \\
TV & $70-150$ & 1 & 5 & $350-750$ \\
Radio & 15 & 1 & 2 & 30 \\
Refrigerator & 100 & 1 & 24 & $1200 *$ \\
Cellphone & $5-10$ & 2 & 2 & $20-40$ \\
Fan & 100 & 2 & 3 & 600 \\
Miscellaneous & & & & $100-300$ \\
Total & & & & $\mathbf{2 5 0 0 - 2 9 4 0}$ \\
\hline
\end{tabular}

* Average consumption of refrigerator whenever compressor is on.

Majority of rural areas have agriculture as their main occupation. Hence providing water for irrigation becomes an integral part of SIRES. Crops have growing cycles of 100-150 days. A typical requirement will be $30-130 \mathrm{~m}^{3} /$ ha range (3-13 mm/day) [31]. As mentioned earlier, 80 hectares need 
to be irrigated. Based on the references and considering efficient irrigation, it is estimated that $30-60 \mathrm{~m}^{3}$ per hectare per day, or about $100-200 \mathrm{~m}^{3}$ per hour is required for the entire irrigated land. Typical annual precipitation in the study area is 37.29 inches $(941 \mathrm{~mm}$ ) [32]. Effective rainfall for crops is believed to be $70 \%(660 \mathrm{~mm})$. Therefore the water required will be $75-175 \mathrm{~m}^{3} / \mathrm{h}$.

\subsubsection{Analysis of Availability and Conditions}

The rural area considered is assumed to have ample water resources from rivers and streams with adequate sunshine and medium to high wind speeds around the year. Most people have agriculture as their major occupation and hence a significant amount of agriculture and animal waste is generated that can be used to produce biogas. Based on these, resources that could be inputs to SIRES are biomass, water, solar and wind. Striking features of biomass is that it is widely and readily available, simple to use and low cost. Biomass is used largely and inefficiently at present in rural areas for cooking and heating purposes. One method to use biomass efficiently is to convert it into biogas. It is produced when collected biomass undergoes an anaerobic fermentation in bio-digesters. Heating value of biogas is about $4600-6000 \mathrm{kcal} / \mathrm{m}^{3}$. As mentioned earlier, number of cattle in rural area is assumed to be 450 and irrigated land in 80 acres. Approximately 9 tons of wet animal and human dung is produced every day. This is equivalent to about $300 \mathrm{~m}^{3}$ of biogas. About 1 ton of dry crop residue is considered which generates about $50 \mathrm{~m}^{3}$ of biogas. Hence $350 \mathrm{~m}^{3}$ of biogas is produced every day [33]. The slurry that remains after biogas production is rich in nutrients and can be used as fertilizer for crops. Biogas production is assumed to be constant throughout the day. Hourly solar irradiation and wind data are obtained from the Climate and Data Services, Oklahoma Climatological Survey. Ample water is available from the river and lakes.

\subsubsection{Priortization and Selection of Technologies}

As discussed earlier, the advantage of SIRES is prioritization of needs and resources to fulfill basic requirements of rural area. Hence in the first stage, resources are matched to needs in a smart and efficient manner. The order of priority of needs based on everyday use is decided empirically: cooking, potable and drinking water, electricity, irrigation water. Order of priority of resources can be also decided empirically based on the need. For cooking, highest priority is given to biogas followed by solar cookers and finally electricity. For water pumping, highest priority is given to solar and wind resources followed by biogas powered water pumps. For electricity, priority is given to solar and wind resources followed by pico hydropower, biogas and electricity stored in batteries. Additional discussion on the selection of technologies can be found in [26].

\subsection{Modeling of System Components}

All the models presented in this section are based on hourly values of the quantities of interest and hence can be classified as hourly models. Equations (1)-(15) define the modeling of system components such as biogas generator, pico hydropower generator, PV panels, Wind turbines, wind driven mechanical pumps, PV powered water pumps, biogas powered water pumps, battery bank and biogas digester. On a given $i$ th day and at time ' $t$ ', the following models apply for various components.

A biogas generator consists of biogas digesters, a biogas collection tank, a biogas-driven engine generator as well as piping and controls for successful operation. Equation (1) represents the biogas generator model [34].

$$
P_{\text {bio }}(t)=n_{\text {bio }} \times V_{\text {bio }}(t) \times \text { Energy Equivalent of biogas }\left(5.6 \mathrm{kWh} / \mathrm{m}^{3}\right)
$$

where $P_{b i o}(t)$ is energy generated by biogas generator $(\mathrm{kWh}), V_{b i o}(t)$ is volume of biogas $\left(\mathrm{m}^{3}\right)$ and $n_{b i o}$ is efficiency of biogas generator 
When a water discharge $Q_{t}\left(\mathrm{~m}^{3} / \mathrm{s}\right)$ passes through the plant, the delivered power of a picohydro power plant is calculated as shown in Equation (2).

$$
P_{\text {hydro }}(t)=\rho_{w} \times g \times Q_{t}(t) \times H_{d}
$$

$P_{\text {hydro }}(t)$ is energy generated by picohydro powerplant $(\mathrm{kWh}), \rho_{w}$ is the density of water $\left(1000 \mathrm{~kg} / \mathrm{m}^{3}\right)$, $\mathrm{g}$ is Acceleration due to gravity $\left(9.8 \mathrm{~m} / \mathrm{s}^{2}\right)$ and $H_{d}$ is effective height of the reservoir $(\mathrm{m})$.

A PV array consists of $N_{p}$ modules in parallel and $N_{s}$ modules in series at an inclination angle $\beta$. Electric power generated by PV panels $\left(P_{P V}^{i}(t, \beta)\right)$ in $\mathrm{kWh}$ is expressed in Equations (3)-(6) [35].

$$
\begin{aligned}
P_{P V}^{i}(t, \beta) & =N_{s} \times N_{p} \times V_{o c}^{i}(t) \times I_{s c}^{i}(t, \beta) \times F F^{i}(t) \\
I_{s c}^{i}(t, \beta) & =\left\{I_{S C, S T C}+K_{1}\left[T_{C}^{i}(t)-25^{\circ} \mathrm{C}\right]\right\} \times \frac{G^{i}(t, \beta)}{1000} \\
V_{O C}^{i}(t) & =V_{O C, S T C}-K_{V} \times T_{C}^{i}(t) \\
T_{C}^{i}(t) & =T_{A}^{i}(t)+\frac{N C O T-20^{\circ} \mathrm{C}}{800} G^{i}(t, \beta)
\end{aligned}
$$

where $V_{o c}^{i}(t)$ is open-circuit voltage, $V_{O C, S T C}$ is open-circuit voltage under Standard Test Conditions (STC), $K_{V}$ is open-circuit temperature coefficient $\left(\mathrm{V} /{ }^{\circ} \mathrm{C}\right), I_{S C}^{i}(t, \beta)$ is PV module short-circuit current (A), $I_{S C, S T C}$ is short-circuit current under STC $(\mathrm{A}), G^{i}(t, \beta)$ is global irradiance $\left(\mathrm{W} / \mathrm{m}^{2}\right)$, $K_{1}$ is short-circuit temperature coefficient $\left(\mathrm{A} /{ }^{\circ} \mathrm{C}\right), T_{A}^{i}(t)$ is Ambient temperature $\left({ }^{\circ} \mathrm{C}\right), T_{C}^{i}(t)$ is cell temperature $\left({ }^{\circ} \mathrm{C}\right)$, NCOT is Nominal Cell Operating Temperature $\left({ }^{\circ} \mathrm{C}\right)$ provided by the manufacture and $F F^{i}(t)$ is Fill Factor.

Power output from wind system $\left(P_{W G}^{i}(t)(\mathrm{kWh})\right)$ is expressed as a function of wind speed. A simple model for the wind system output is presented in Equation (7) [17].

$$
P_{W G}^{i}(t)= \begin{cases}P_{r} \frac{v^{i}(t, h)-v_{c}}{v_{r}-v_{c}} & v_{c} \leq v^{i}(t, h) \leq v_{r} \\ P_{r} & v_{r} \leq v^{i}(t, h) \leq v_{f} \\ 0 & \text { else }\end{cases}
$$

where $P_{r}$ is rated electrical power $(\mathrm{kW}), v_{c}, v_{r}$ and $v_{f}$ cut-in, rated and cut-off wind speed in $\mathrm{m} / \mathrm{s}$ respectively. $v^{i}(t, h)$ is wind speed at desired wind turbine installation height $h$.

Modeling of wind mechanical water pump $\left(Q_{W G}(t)\right)$, PV powered water pump $\left(Q_{P V}(t)\right)$ and biogas powered water pump $\left(Q_{b i o}(t)\right)$ is shown in Equation (8), (9) and (10) respectively $[31,36,37]$.

$$
\begin{aligned}
Q_{W G}^{i}(t) & =\frac{1}{8} \eta_{p d} C_{p d} v^{i}(t) D_{T} \frac{\rho_{a}}{\rho_{w}}\left[\frac{G \lambda_{d}}{N_{p d}}\right] \frac{V_{d}^{3}}{g H_{d}} \\
Q_{P V}^{i}(t) & =\frac{\left(N_{s} \times N_{p}\right) \times \eta_{p} \times P_{P V}^{i}(t, \beta)}{\rho_{w} \times g \times H_{d}} \\
Q_{b i o}^{i}(t) & =\frac{\eta_{\text {pump }} \times \eta_{\text {engine }} \times V_{\text {bio }}^{i}(t) \times 5.6 \times 367}{H_{d}}
\end{aligned}
$$

For wind mechanical water pump, $\eta_{p d}$ is efficiency of the pump at design point, $\rho_{a}$ is density of $\operatorname{air}\left(\mathrm{kg} / \mathrm{m}^{3}\right), D_{T}$ is diameter of the wind rotor $(\mathrm{m}), V_{d}$ is design wind velocity $\left(\mathrm{m} / \mathrm{s}^{2}\right), C_{p d}$ is design power co-efficient of the wind rotor, $N_{p d}$ is speed of the pump at design point $\left(\mathrm{m} / \mathrm{s}^{2}\right), \mathrm{G}$ is gear ratio and $\lambda_{d}$ is design tip speed ratio of the wind rotor. $\eta_{p}, \eta_{p u m p}$ and $\eta_{\text {engine }}$ is efficiency of $\mathrm{pv}$ water pump, biogas water pump and biogas engine respectively. 
Battery modeling expressions are given in Equations (11)-(14) [17,33].

$$
\begin{aligned}
C_{\min }= & D O D \times C_{n} \\
P_{B}^{i}(t)= & P_{W G}^{i}(t)+P_{P V}^{i}(t, \beta)+P_{\text {hydro }}^{i}(t) \\
& +P_{\text {bio }}^{i}(t)-P_{\text {load }}^{i}(t) \\
C^{i}(t)= & C^{i}(t-1)+\eta_{b} \frac{P_{B}^{i}(t)}{V_{D C, \text { bus }}} \Delta t \\
C^{i}(24)= & C^{i+1}(0)
\end{aligned}
$$

where $P_{B}^{i}(t)$ is battery input/output energy $(\mathrm{kWh}), P_{\text {load }}^{i}(t)$ is energy needed to fulfill the electricity load $(\mathrm{kWh}), C_{\min }$ is the minimum permissible battery capacity, DOD is maximum permissible Depth Of Discharge, $C_{n}$ is nominal capacity, $C^{i}(t)$ is available battery capacity (Ah) and $V_{D C, b u s}$ is DC bus voltage $(\mathrm{V}) . \eta_{\text {inverter }}$ and $\eta_{b}$ is efficiency of inverter and battery respectively. $\Delta t$ is simulation time step and is equal to 1 .

When biomass undergoes anaerobic fermentation in the digester, biogas is produced. Volume of biogas digester $\left(D_{V}\right)$ is given by Equation (15)

$$
D_{V}=\left[\text { manure }\left(\mathrm{m}^{3} / \text { year }\right)+c o-\operatorname{substrate}\left(\mathrm{m}^{3} / \text { year }\right] \times \frac{\text { retentiontime }(\text { days })}{365}\right.
$$

\subsection{Modeling of System Reliability and Annualized Cost of System}

\subsubsection{System Reliability}

Reliability is the probability of a device performing its purpose adequately for the period of time intended under operating conditions encountered. Loss of Power Supply Probability (LPSP) and Loss of Water Supply Probability (LWSP) are considered as measures of reliability in SIRES. For a considered period, LPSP is the ratio of all the loss of power supply over the total load required during that period. It is defined as the probability that an insufficient power supply results when the hybrid system is unable to satisfy the load demand [19].

LPSP, from time 1 to $\mathrm{T}$ can be described as,

$$
L P S P=\frac{\sum_{t=1}^{T} L P S}{\sum_{t=1}^{T} P_{\text {load }}(t) \Delta t}
$$

Loss of power supply (LPS) at hour $t$ can be expressed as

$$
\begin{array}{r}
\text { LPS }=P_{\text {load }}(t) \Delta t-\left(\left(P_{W G}(t)+P_{P V}(t)+P_{\text {hydro }}(t)\right.\right. \\
\left.\left.+P_{\text {bio }}(t)\right) \Delta t+C(t-1)-C_{\text {min }}\right) \eta_{\text {inverter }}
\end{array}
$$

where $\Delta t$ is the step of time used for calculations. In this study, it is considered to be 1 . During the time step, power generated by wind turbine, PV module, pico hydropower plant and biogas generator is assumed to be constant.

Based on the LPSP concept, another probability called Loss of water supply probability (LWSP) is introduced. Since SIRES has multiple outputs, it is mandatory to build reliability model for each output, one of them being water supply for potable, domestic and irrigation purposes. For a considered period, LWSP is the ratio of all the loss of water supply over the total water required during that period.

LWSP, from time 1 to $\mathrm{T}$ can be described as,

$$
L W S P=\frac{\sum_{t=1}^{T} L W S}{\sum_{t=1}^{T} W_{\text {load }}(t) \Delta t}
$$


where $W_{\text {load }}(t)$ is amount of water required to fulfill needs $\left(\mathrm{m}^{3}\right)$.

Loss of water supply (LWS) for an hour $t$ can be expressed as

$$
L W S=W_{\text {load }}(t) \Delta t-\left(\left(Q_{W G}(t)+Q_{P V}(t)+Q_{\text {bio }}(t)+Q_{S H}(t)\right) \Delta t\right) \eta_{p u m p}
$$

$Q_{S H}(t)$ is water stored in reservoir $\left(\mathrm{m}^{3}\right)$

\subsubsection{Annualized Cost of System}

To identify the optimum combination of system components for SIRES, a tradeoff is made between the two considered objectives: the system reliability and system cost. Cost analysis in this study based on the concept of Annualized Cost of System (ACS). ACS comprises of annualized capital cost $\left(C_{c c}\right)$, annualized replacement $\operatorname{cost}\left(C_{r c}\right)$ and annualized maintenance cost $\left(C_{m c}\right)$. Main components of SIRES considered for the economic model are biogas digester $\left(B_{D}\right)$, biogas powered generator $\left(B_{G}\right)$, biogas powered water pump $\left(B_{P}\right)$, hydro-turbine $\left(H_{T}\right)$, wind turbine $\left(W_{T}\right)$, wind powered water pump $\left(W_{P}\right)$, PV panel $\left(P_{E}\right), \mathrm{PV}$ powered water pump $\left(P_{P}\right)$ and battery bank $\left(C_{B}\right)$.

Annualized capital cost $\left(C_{c c}\right)$ of each component takes into account the installation cost and can be given as [19],

$$
C_{c c}=C_{i j} \cdot C R F\left(r, n_{i j}\right)
$$

where $C_{i j}$ is the capital cost of equipment that uses $i$ th resource to fulfill the $j$ th task (\$), $n_{i j}$ is the lifetime in years for $i$ th- $j$ th combination, $r$ is the annual rate of interest and CRF is the Capital Recovery Factor. $C R F$ can be defined as a ratio to calculate the present value of an annuity (a series of equal annual cash flows) and can be expressed as

$$
C R F=\left(\frac{r(1+r)^{n_{i j}}}{(1+r)^{n_{i j}}-1}\right)
$$

Annual rate of interest is related to nominal interest rate $r^{\prime}$ and the annual inflation rate $f$ by the equation given below

$$
r=\frac{r^{\prime}-f}{1+f}
$$

Annualized replacement cost of a system component is the annualized value of all the replacement costs occurring throughout the lifetime of the project and is given as

$$
C_{r c}=C_{r e p} \cdot \operatorname{SFF}\left(r, n_{\text {rep }}\right)
$$

where $C_{\text {rep }}$ is the replacement cost of equipment (\$), $n_{\text {rep }}$ is the component lifetime in years and SFF is the sinking fund factor. SFF is a ratio to calculate the future value of an annuity and is given as

$$
S F F=\left(\frac{r}{(1+r)^{n_{r e p}}-1}\right)
$$

System maintenance cost, which includes inflation rate $f$ is given as,

$$
C_{m c}(n)=C_{m c}(1) \cdot(1+f)^{n}
$$

where $C_{m c}(n)$ is the maintenance cost of the $n$th year.

Then ACS for water supply is given as

$$
A C S_{w}=C_{c c}\left(B_{p}+W_{p}+P_{p}\right)+C_{m c}\left(B_{p}+W_{p}+P_{p}\right)+C_{r e p}\left(B_{p}\right)
$$


And ACS for electricity supply is given as

$$
\begin{aligned}
A C S_{e}= & C_{c c}\left(B_{G}+W_{T}+P_{E}+H_{T}+C_{B}\right)+C_{m c}\left(B_{G}\right. \\
& \left.+W_{T}+P_{E}+H_{T}+C_{B}\right)+C_{r e p}\left(B_{G}++C_{B}\right)
\end{aligned}
$$

\subsection{Application of GA to SIRES}

Genetic Algorithm (GA) is an advanced search and optimization technique. It is robust in finding global optimal solutions especially for multi-objective optimization problems, as it is population-based approach. A single-objective GA can be easily transformed into a multi-objective to find a set of multiple non-dominated solutions in a single run. GA has the ability to simultaneously search different regions of a solution space. This makes it possible to find a diverse set of solutions for complex problems with discontinuous, non-convex and multi-modal solution spaces. Another advantage of multi-objective GA is that most of GAs' do not require prioritization, scale, or weigh objectives $[19,38]$.

In the proposed method, optimum number of biogas digester $\left(B_{D}\right)$, biogas powered generator $\left(B_{G}\right)$, biogas powered water pump $\left(B_{P}\right)$, hydro-turbine $\left(H_{T}\right)$, wind turbine $\left(W_{T}\right)$, wind powered water pump $\left(W_{P}\right)$, PV panel $\left(P_{E}\right)$, PV powered water pump $\left(P_{P}\right)$ and battery bank $\left(C_{B}\right)$ is generated using Genetic Algorithm such that the 25-year lifetime annualized cost is minimized. The optimum number of system components along with the height of wind turbine comprise the set of decision variables. One year of hourly data for solar radiation, ambient air temperature, wind speed, water availability, biogas availability, load power consumption, domestic and irrigation water demand and cooking demand is used in the model.

Initial assumptions for the system configuration are subject to the following constraints:

$$
\operatorname{Min}\left(B_{G}, B_{P}, H_{T}, W_{T}, P_{E}, P_{P}, C_{B}\right) \geq 0
$$

Subject to:

$$
\begin{array}{r}
L P S P_{\min } \leq L P S P \leq L P S P_{\max } \\
L W S P_{\text {min }} \leq L W S P \leq L W S P_{\text {max }} \\
C_{\text {min }}(t) \leq C^{i}(t) \leq C_{\text {max }}(t) \\
h_{\text {low }} \leq h \leq h_{\text {high }}
\end{array}
$$

A genetic algorithm for optimal sizing of SIRES is formulated to minimize ACS subject to reliability. An initial population of a set of chromosomes which forms the first generation, is randomly generated and the constraints are evaluated for each chromosome. If any chromosome of the initial population violates the constraints, then it is replaced by a new chromosome that fulfills these constraints. The chromosome for genetic algorithm has 9 genes and is of the form $\left[P_{E}\left|W_{T}\right| B_{G}\left|H_{T}\right| h \mid\right.$ $\left.C_{B}\left|P_{P}\right| W_{P} \mid B_{P}\right]$

Energy produced by renewable technologies of SIRES is calculated. The system configuration is then optimized by employing a genetic algorithm, which dynamically searches for the optimal configuration to minimize ACS. For every system configuration, the system's LPSP and LWSP is calculated and verified if it meets the set target. The lower cost configurations is subject to the crossover and mutation operations of the GA. This step produces the next generation population. The process continues till a criterion that determines convergence is satisfied. Optimal configuration for the desired LPSP and LWSP is identified both technically and economically from the set of configurations by achieving the lowest ACS. The flowchart of optimization process is illustrated in Figure 4. 


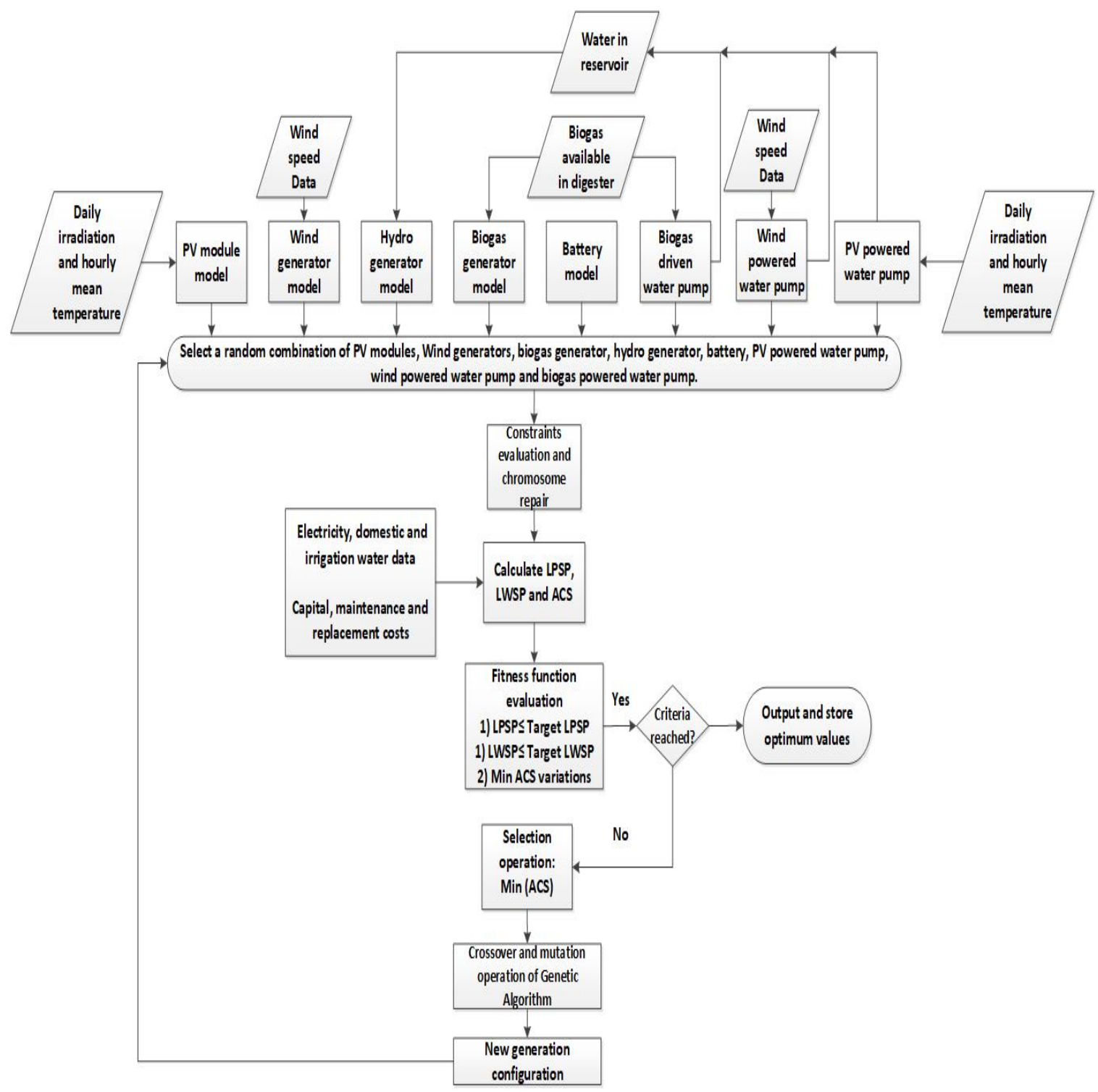

Figure 4. Flowchart for optimal sizing of SIRES using GA.

\section{Results and Discussion}

Optimum combination of system components in SIRES varies as weather conditions and available resources vary during the time in question: for example, hourly, monthly, seasonally or yearly. Therefore, if the system is designed to supply needs throughout the year, then SIRES should be designed accordingly. Hence to obtain an acceptable design of SIRES, one year of hourly data for temperature, wind speed, solar irradiation, water in reservoir and biogas produced is given as input resource data. One year of hourly data for cooking, domestic water, electricity and irrigation water is given as demand data. In this research, the period from 1 September 2014 to 31 August 2015 is chosen as example to represent climatic conditions for the SIRES design and optimization process. Table 3 summarizes the needs required per day. 
Table 3. Summary of Needs Required per day.

\begin{tabular}{ccc}
\hline S1 No. & Purpose/Need & Quantity Per Day \\
\hline 1 & Biogas for cooking & $238-294 \mathrm{~m}^{3}$ \\
2 & Domestic water & $50 \mathrm{~m}^{3}$ \\
3 & Electricity load & $345-415 \mathrm{kWh}^{3}$ \\
4 & Irrigation water & $2000-4800 \mathrm{~m}^{3}$ \\
\hline
\end{tabular}

Table 4 gives the related capital costs, maintenance costs and replacement costs, which are also inputs to optimal sizing procedure for SIRES [39-42]. Capital cost of the system components includes installation cost. Replacement cost is considered for biogas generator, battery and biogas powered water pump. Lifetime of the system is considered to be 25 years. Technical characteristics of all system components used in SIRES are summarized in Table 5 [19,43-46].

Table 4. Capital cost, Maintenance cost and Replacement cost for System Components.

\begin{tabular}{lllll}
\hline Component & $\begin{array}{l}\text { Capital Cost } \\
\text { (Per Unit) }\end{array}$ & $\begin{array}{l}\text { Maintenance } \\
\text { Cost (Year) }\end{array}$ & $\begin{array}{l}\text { Replacement } \\
\text { Cost }\end{array}$ & $\begin{array}{l}\text { Lifetime } \\
\text { (Years) }\end{array}$ \\
\hline Solar PV & $\$ 3000 / \mathrm{kW}$ & $\$ 65$ & $\$ 0$ & 25 \\
Wind Turbine & $\$ 1800 / \mathrm{kW}$ & $\$ 95$ & $\$ 0$ & 25 \\
Biogas Digester & $\$ 65 / \mathrm{m}^{3}$ & $\$ 100$ & $\$ 0$ & 25 \\
Biogas Generator & $\$ 1200 / \mathrm{kW}$ & $\$ 100$ & $\$ 1000$ & 8 \\
Reservoir & $\$ 2000 / \mathrm{acre}-\mathrm{ft}$ & $\$ 50$ & $\$ 0$ & 25 \\
Pico Hydropower & $\$ 2300 / \mathrm{kW}$ & $\$ 15$ & $\$ 0$ & 25 \\
Battery & $\$ 1500 / \mathrm{kAh}$ & $\$ 50$ & $\$ 1500$ & 8 \\
Wind powered water pump & $\$ 1000 / \mathrm{pump}$ & $\$ 100$ & $\$ 0$ & 25 \\
Solar powered water pump & $\$ 6000 / \mathrm{kW}$ & $\$ 50$ & $\$ 0$ & 25 \\
Biogas powered water pump & $\$ 2500 / \mathrm{kW}$ & $\$ 100$ & $\$ 2500$ & 25 \\
Diesel Generator & $\$ 500 / \mathrm{kW}$ & $\$ 135$ & $\$ 500$ & 8 \\
Other components & $\$ 10,000$ & $\$ 80$ & $\$ 0$ & 25 \\
\hline
\end{tabular}

Table 5. Technical Specifications of System Components.

\begin{tabular}{ll}
\hline \multicolumn{1}{c}{ Specifications } & \multicolumn{1}{c}{ Values } \\
\hline \multicolumn{1}{c}{ Solar PV module specifications } \\
\hline Open-Circuit Voltage (Voc) & $44.6 \mathrm{~V}$ \\
Optimum Operating Voltage(Vmp) & $36.0 \mathrm{~V}$ \\
Short-Circuit Current (Isc) & $3.03 \mathrm{~A}$ \\
Optimum Operating Current(Imp) & $2.78 \mathrm{~A}$ \\
Maximum Power at STC (Pmax) & $100 \mathrm{Wp}$ \\
Module Efficiency & $13.8 \%$ \\
Nominal Operating Cell & $48 \pm 3{ }^{\circ} \mathrm{C}$ \\
Temperature (NOCT) & $0.36 \% /{ }^{\circ} \mathrm{C}$ \\
Temperature Coefficient of Voc & $+0.06 \% /{ }^{\circ} \mathrm{C}$ \\
Temperature Coefficient of Isc & $1090 \times 665 \times 35 \mathrm{~mm}$ \\
Module Dimensions & \\
\hline \multicolumn{1}{c}{ Wind turbine specifications } \\
Cut-in Wind Speed & $2.5 \mathrm{~m} / \mathrm{s}$ \\
Rated Speed & $11 \mathrm{~m} / \mathrm{s}$ \\
Furling Speed & $13 \mathrm{~m} / \mathrm{s}$ \\
Rated power & $1 \mathrm{~kW}$ \\
Rotor Diameter & $2.5 \mathrm{~m}$ \\
\hline
\end{tabular}


Table 5. Cont.

\begin{tabular}{|c|c|}
\hline Specifications & Values \\
\hline \multicolumn{2}{|c|}{ Pico-Hydro power specifications } \\
\hline Height of reservoir & $20 \mathrm{~m}$ \\
\hline Flow rate & $10 \mathrm{~L} / \mathrm{s}$ \\
\hline Efficiency & $70 \%$ \\
\hline \multicolumn{2}{|c|}{ Biogas Digester specifications } \\
\hline Size $\left(\mathrm{m}^{3}\right)$ & 140 \\
\hline \multicolumn{2}{|c|}{ Biogas Generator specifications } \\
\hline Efficiency of generator & $70 \%$ \\
\hline \multicolumn{2}{|c|}{ Wind powered water pump } \\
\hline Rotor diameter & $5 \mathrm{~m}$ \\
\hline Tower height & $20 \mathrm{~m}$ \\
\hline Pump diameter & $200 \mathrm{~mm}$ \\
\hline \multicolumn{2}{|c|}{ Solar powered water pump } \\
\hline Maximum suction lift & $3 \mathrm{~m}$ \\
\hline Minimum PV array power & $1.1 \mathrm{~kW}$ \\
\hline Maximum Amp & $22.3 \mathrm{~A}$ \\
\hline Pump rate & 30 gpm \\
\hline \multicolumn{2}{|c|}{ Biogas powered water pump } \\
\hline Power rating & $3.8 \mathrm{~kW}$ \\
\hline Efficiency & $50 \%$ \\
\hline \multicolumn{2}{|c|}{ Overhead Reservoir } \\
\hline Size (acre-foot) & 5 acre-feet \\
\hline \multicolumn{2}{|c|}{ Battery Specifications } \\
\hline Rated Capacity, Voltage & $1000 \mathrm{Ah}, 24 \mathrm{~V}$ \\
\hline Charging Efficiency & $90 \%$ \\
\hline
\end{tabular}

\subsection{Optimal Sizing and Cost Analysis}

Optimal sizing is carried out in MATLAB using global optimization toolbox. It contains heuristic algorithms such as the genetic algorithm, particle swarm optimization and so on. A MATLAB code is written with the aid of genetic algorithm toolbox functions. Three random days are selected from every month for the considered year as providing one-year of data slows down the optimal sizing process. An initial population of 50 chromosomes that forms the 1st generation is randomly generated subject to the upper and lower bound constraints of genes. The GA code is repeated for 200 generations (iterations). Target LPSP and LWSP is set as $1 \%$. Solar and wind energy is given the highest priority to fulfill electricity and pumping water needs because biogas is primarily used for cooking and water stored in reservoir fulfills water demands.

For ACS calculations, the lifetime of SIRES is considered to be 25 years. Nominal interest rate ( $r$ ') is assumed to be $3.75 \%$ at an inflation rate of $1.5 \%$. Net present cost (NPC) for a period of 25 years can be calculated as [47],

$$
\text { Net Present Cost }(N P C)=\frac{A C S}{\operatorname{CRF}(r, n)}
$$

$C R F$ is the Capital Recovery Factor for ' $r$ ' rate of interest and ' $n$ ' years. $C R F$ for the considered case is 0.0524 . With the NPC, costs are positive and revenues are negative. This is the opposite of the Net Present Value (NPV). As a result, the NPC differs from NPV only in sign [48]. 
Internal Rate of Return (IRR) is another measure of using the discounted cash flow for arriving at the worth of the project and it is obtained at NPV $=0$. Higher IRR signifies greater capacity of the project to generate benefits over a period of time [49]. In this work, the Microsoft Excel function IRR was used to obtain IRR for the considered cases.

\subsection{Cost Comparison for Various Approaches of Rural Development}

SIRES is cost compared to common approaches of rural development such as grid extension, microgrid with and without diesel generator.

\subsubsection{SIRES}

Appliances for lighting and communication such as light bulbs, TV, radio, cell phones, fans, refrigerator and miscellaneous appliances are considered for electricity consumption for rural area. The best ACS is $\$ 13,950.2$ and the corresponding initial installation cost is $\$ 122,900$. Net present cost for SIRES is $\$ 266,225.19$. Figure 5 shows the variations of ACS during the GA optimization process. The order of system components is same as the chromosome order discussed earlier. Optimal sizing of system components of SIRES is shown in Figure 6.

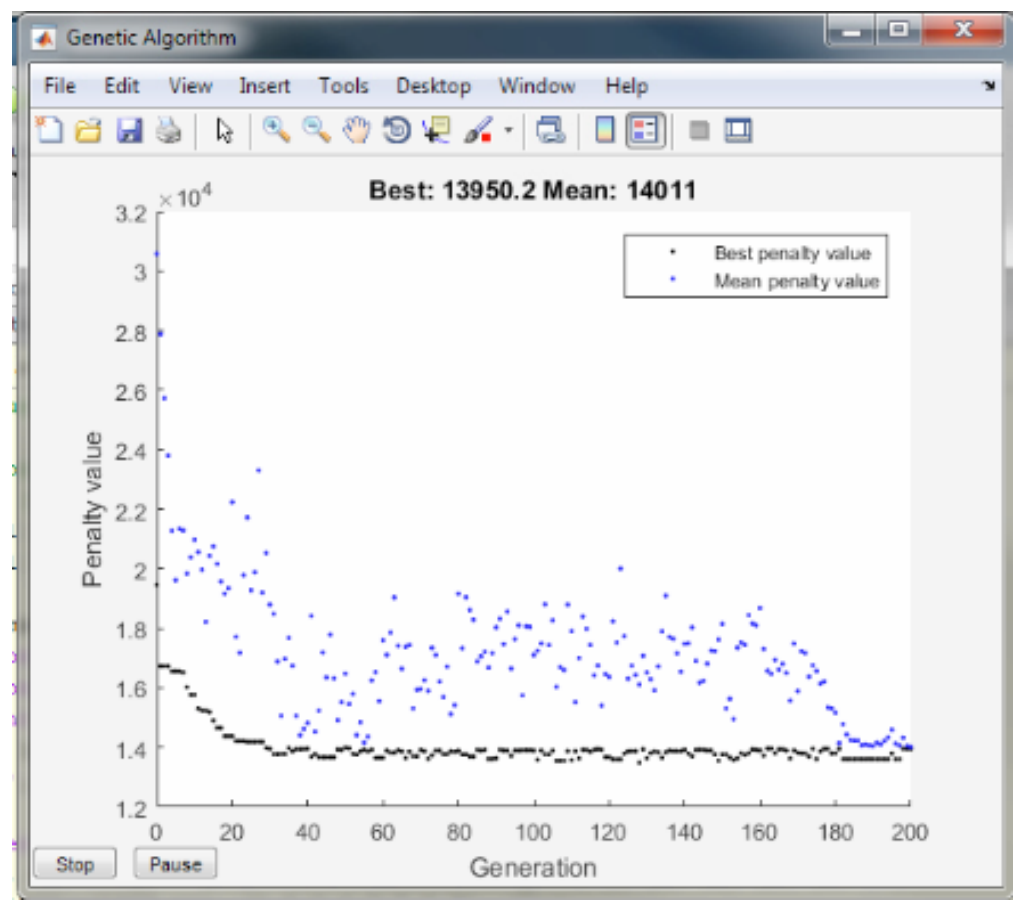

Figure 5. Variations of ACS during GA optimization process for SIRES.

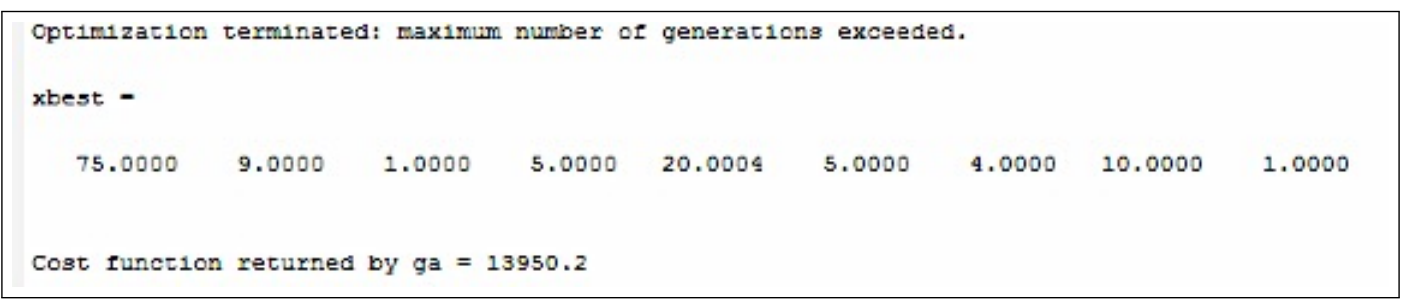

Figure 6. Optimal Sizing of System Components for SIRES.

\subsubsection{Grid Extension}

Grid extension or Rural Electrification has several drawbacks as discussed earlier. However several countries continue to follow this traditional method to electrify rural areas. Typical costs for 
grid extension were discussed earlier. Assume average cost for extending the national grid is $\$ 6000$ and rural area is $50 \mathrm{~km}$ (30 miles) away from the main grid. This implies that the cost of extending grid to rural area is $\$ 300,000$.

\subsubsection{Microgrid with Diesel Generator(MDG)}

Over the past few years, microgrids are gaining importance to develop rural areas. Renewable energy technologies such as solar, wind and biogas are coupled with diesel generators to provide electricity to rural areas are considered in this case. Major drawback of microgrids with diesel generators is availability of diesel in remote rural areas and pollution caused by burning diesel that leads to global warming. Electricity equivalent of $0.05 \mathrm{~m}^{3}$ of biogas used for cooking is $0.17 \mathrm{kWh}$ [50]. Energy required to pump water ( $\left.E_{\text {pump }}\right)$ to overhead reservoir can be given as [37],

$$
E_{\text {pump }}=\frac{Q \times H_{d}}{\eta_{\text {pump }} \times 367}
$$

where $Q$ is the amount of water to be pumped every day and $H_{d}$ is effective height of reservoir. In this case, $Q$ is equal to $3600 \mathrm{~m}^{3}$ and $H_{d}$ is equal to $20 \mathrm{~m}$. $\eta_{\text {pump }}$ is efficiency of pump is $50 \%$. Energy needs fulfilled by SIRES per day are converted to electricity and are given in Table 6. Figure 7 shows ACS variations during GA optimization process for microgrid with diesel generator. Optimal sizing of systems components of microgrid with diesel generator is shown in Figure 8. The best ACS is equal to $\$ 26,296.4$ and the corresponding initial installation cost is $\$ 217,000$. Net present cost for this case is $\$ 501,839.69$. The order of xbest is $\left[P_{E}\left|W_{T}\right| B_{G}\left|H_{T}\right| h\left|C_{B}\right| D_{G}\right]$, where $D_{G}$ is diesel generator.

Table 6. Needs fulfilled by SIRES converted to Electricity.

\begin{tabular}{ccc}
\hline Needs & SIRES & Microgrid \\
\hline Cooking & $250 \mathrm{~m}^{3}$ of Biogas & $850 \mathrm{kWh}$ \\
Pumping Water & $3600 \mathrm{~m}^{3}$ of Water & $400 \mathrm{kWh}$ \\
Electricity & $300 \mathrm{kWh}$ & $300 \mathrm{kWh}$ \\
\hline
\end{tabular}

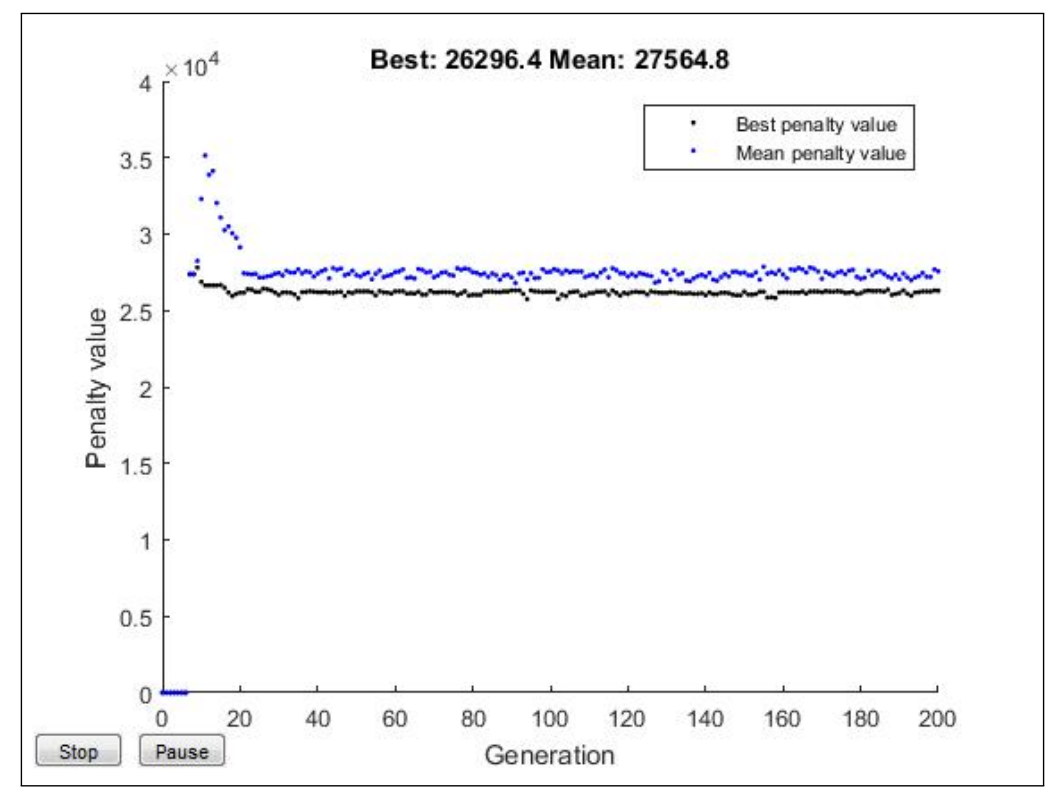

Figure 7. Variations of ACS during GA optimization process for diesel generator. 


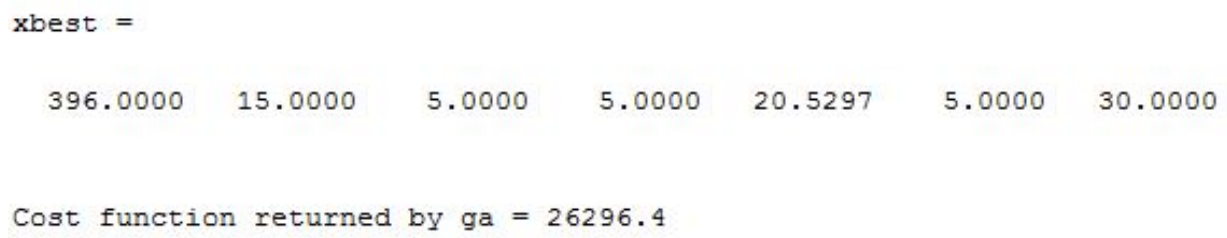

Figure 8. Optimal Sizing of System Components for diesel generator.

\subsubsection{Microgrid Without Diesel Generator(MWDG)}

In this case, microgrid uses renewable energy resources such as solar, wind, hydropower and biogas to fulfill the electricity demand. In other words, the same resources that are input to SIRES are used in the considered microgrid case. A vital difference is microgrid "electrifies" the rural area whereas SIRES "energizes" it. If microgrid is used to fulfill all needs, then the annualized cost of system is $\$ 22,197.9$ and initial installation cost is $\$ 225,300$. Net present cost for this case is $\$ 423,624.04$. Optimal sizing of systems components of microgrid without diesel generator is shown in Figure 9. The order of xbest is $\left[P_{E}\left|W_{T}\right| B_{G}\left|H_{T}\right| h \mid C_{B}\right]$. Figure 10 shows ACS variations during the GA optimization process.

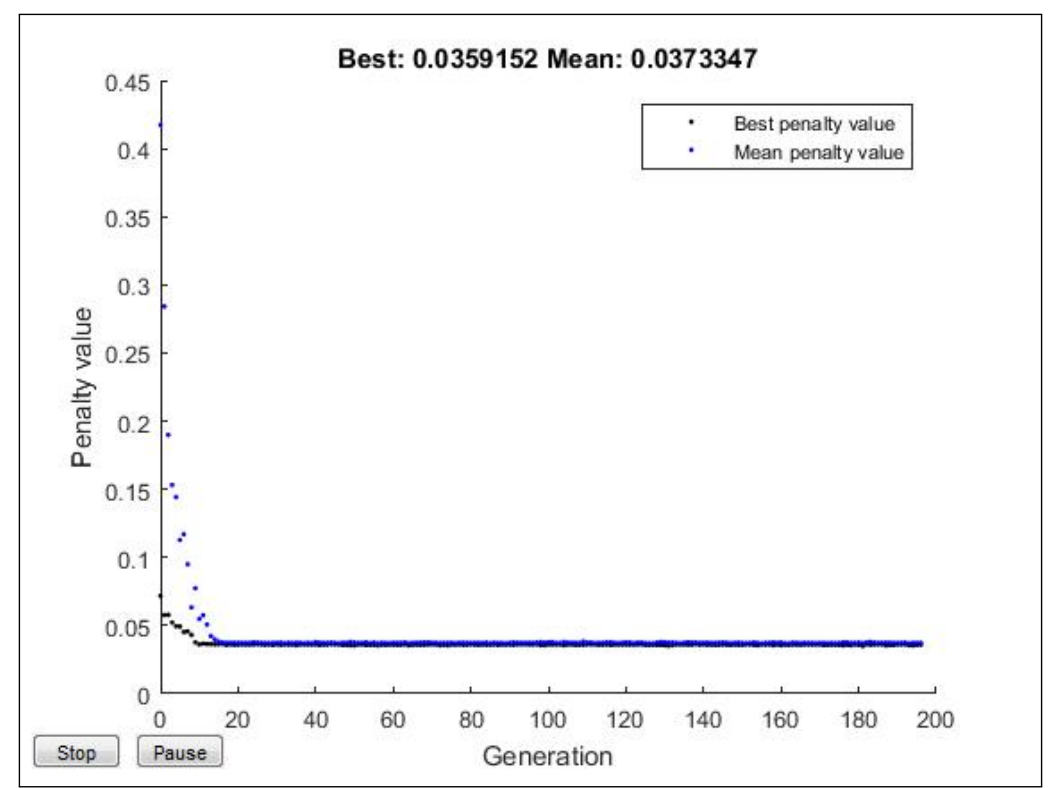

Figure 9. Variations of ACS during GA optimization process for microgrid without diesel generator.

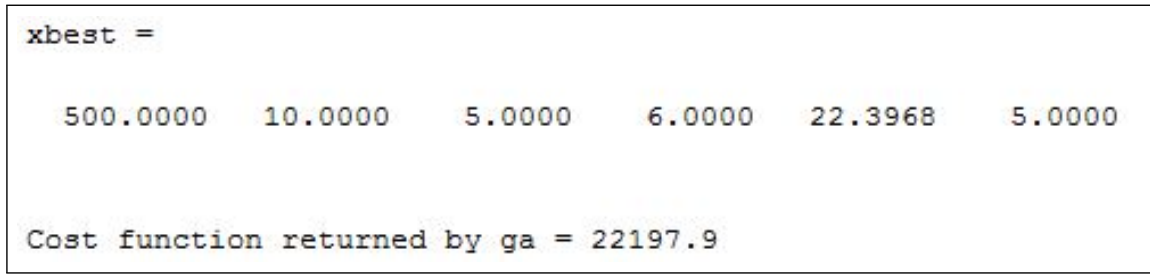

Figure 10. Optimal Sizing of System Components for microgrid without diesel generator.

Table 7 gives a cost comparison of various approaches used to fulfill same amount of needs. It is clearly evident that SIRES is a more cost effective system to fulfill the same amount of needs as compared to grid extension, microgrid with diesel generator and microgrid without diesel generator. Another note-worthy point is the installation cost for MDG is less when compared to MWDG. However, 
net present cost for MDG is higher when compared with MWDG due to the usage of diesel fuel for a period of 25 years. IRR for MWDG is the least and highest for MDG. However, MDG will have adverse effects on the environment as compared to the proposed SIRES.

Table 7. Cost Comparison of various Approaches to Rural Development.

\begin{tabular}{|c|c|c|c|c|}
\hline $\begin{array}{l}\text { Approach to } \\
\text { Rural Development }\end{array}$ & $\begin{array}{l}\text { Grid } \\
\text { Extension }\end{array}$ & $\begin{array}{l}\text { Microgrid with } \\
\text { Diesel Generator } \\
\text { (MDG) }\end{array}$ & $\begin{array}{l}\text { Microgrid without } \\
\text { Diesel Generator } \\
\text { (MWDG) }\end{array}$ & SIRES \\
\hline Annualized Cost of System & - & $\$ 26,296.4$ & $\$ 22,197.9$ & $\$ 13,950.2$ \\
\hline Initial Installation Cost & $\$ 300,000$ & $\$ 217,000$ & $\$ 225,300$ & $\$ 122,900$ \\
\hline Net Present Cost (NPC) & - & $\$ 501,839.7$ & $\$ 423,624.04$ & $\$ 266,225.2$ \\
\hline Internal Rate of Return (IRR) & - & $11 \%$ & $9 \%$ & $10 \%$ \\
\hline
\end{tabular}

\section{Concluding Remarks}

For socio-economic development and growth of rural areas, basic needs such as domestic and potable water, cooking and household electricity must be provided in a sustainable manner. Renewable energy resources such as biogas, hydro, insolation and wind are locally available in rural areas and can be harnessed in an efficient manner to fulfill these basic requirements. SIRES offers an effective and viable strategy that can be employed to harness renewable energy resources to "energize" (not just electrify) remote rural areas of developing countries. In this paper, a methodology for optimization of SIRES to minimize ACS and maximize reliability is described. A hypothetical rural area with a population of 700 was considered as an example and basic energy requirements for this area were estimated. Availability of resources and weather conditions were analyzed. Needs were prioritized depending on the daily necessities and suitable renewable technologies were selected. System components, Annualized Cost of System (ACS) and System Reliability were modeled. A flowchart for implementation of genetic algorithm was developed. After the implementation of GA, optimal number of system components and minimum ACS for target reliability was obtained. A similar procedure was followed to obtain ACS for microgrid with and without diesel generator. In addition, installation cost and Net Present Cost (NPC) were calculated. It was found that employment of SIRES costs at about $40 \%$ less when compared with other current approaches including grid extension. Installation of SIRES will also reduce greenhouse gas (GHG) emissions and improve overall efficiency as compared to the current approaches to rural development. Introduction of SIRES in rural communities brings about improvements in living environment and community welfare by supplying the basic needs such as biogas for cooking, water for domestic, potable and irrigation purposes and electrical energy for lighting, communication, cold storage, educational and small- scale industrial needs.

Acknowledgments: Preparation of this paper was supported by the Oklahoma State University Engineering Energy laboratory and PSO/Albrecht Naeter professorship in the School of Electrical and Computer Engineering.

Author Contributions: Author Zeel Maheshwari developed the mathematical models, designed the methodology and wrote the manuscript. Author Rama Ramakumar assisted in writing a few sections, proof read and extensive English editing of the manuscript. He is the originator for the concept of IRES.

Conflicts of Interest: The authors declare no conflict of interest.

\section{Abbreviations}

The following abbreviations are used in this manuscript:

SIRES Smart Integrated Renewable Energy Systems

ACS Annualized Cost of System

LPSP Loss of Power Supply Probability

LWSP Loss of Water Supply Probability

GA Genetic Algorithm

NPC Net Present Cost 
NPV Net Present Value

PV Photovoltaic

CRF Capital Recovery Factor

SFF Sinking Fund Factor

IRR Internal Rate of Return

\section{References}

1. Rolland, S. Rural Electrification with Renewable Energy; ARE Publication: Brussels, Belgium, 2010.

2. Energy for Cooking in Development Countries. International Energy Agency (IEA). Available online: https: //www.iea.org/publications/freepublications/publication/cooking.pdf (accessed on 15 September 2015).

3. Reddy, A.K.N; Subramanian, D.K. In the design of rural energy centers. In Rural Technology; Indian Academy of Sciences; Macmillann India Press: Bangalore, India, 1979; pp. 109-131.

4. Progress on Drinking Water and Sanitation. World Health Organization and UNICEF Joint Monitoring Programme (JMP). May 2014. Available online: http:/ / www.unicef.org/publications/files/JMP_\{\}report_ \{\}2014_\{\}webEng.pdf (accessed on 15 September 2015).

5. Gates, B.; Gates, M. Two Superpowers We Wish We Had. 2016 Annual Letter. 22 February 2016. Available online: https: / www.gatesnotes.com/2016-Annual-Letter (accessed on 8 July 2017).

6. Energy for All: Financing Access for the Poor. Available online: http://www.worldenergyoutlook.org/ media/weowebsite/energydevelopment/weo2011_\{\}energy_\{\}for_\{\}all.pdf (accessed on 15 September 2015).

7. United Nations Development Programme (UNDP). Energizing the Millenium Development Goals. New York, 2005. Available online: http:/ / www.unmillenniumproject.org/goals/ (accessed on 13 June 2017).

8. United Nations Development Programme (UNDP). Sustainable Development Goals. Rio De Janerio, 2012. Available online: http:/ / www.undp.org/content/undp/en/home/sustainable-development-goals.html (accessed on 13 June 2017).

9. Ramakumar, R.; Hughes, W. Renewable Energy Sources and Rural Development in Developing Countries. IEEE Trans. Educ. 1981, 24, doi:10.1109/TE.1981.4321499.

10. Decisions by Topic: Rural Development. United Nations. Sustainable Development Knowledge Platform. Available online: https:// sustainabledevelopment.un.org/topics/ruraldevelopment/decisions (accessed on 9 July 2017).

11. Best Practices of the Alliance for Rural Electrification: What Renewable Energy Can Achieve in Developing Countries. Alliance for Rural Electrification. Available online: http://www.ruralelec.org/fileadmin/ DATA/Documents/06_Publications /Position_papers/ARE_Publication_-_Case_studies_for_renewables_ in_Developing_countries.pdf (accessed on 25 September 2015).

12. Schnitzer, D.; Lounsbury, D.; Carvallo, J.P.; Deshmukh, R.; Apt, J.; Kammen, D.M. Microgrids for Rural Electrification: A Critical Review of Best Practices Based on Seven Case Studies; United Nations Foundation (UNF): Washington, DC, USA, 2014.

13. Ramakumar, R. Technical and Socio-Economic aspects of solar energy and rural development in developing countries. Sol. Energy 1977, 19, 643-649.

14. Ramakumar, R. Renewable Energy Sources and Developing Countries. IEEE Trans. Power Appar. Syst. 1983, PAS-102, doi:10.1109/TPAS.1983.317720.

15. Larsen, R.S.; Welbourn, D.; Wessner, D.; Podmore, R.; Lacourciere, M.; Larsen, A.; Lee, P.; Moulton, R.; Myers, S.; Niboh, M.; et al. "Learning beyond the Light Bulb" among Least Developed Countries based on a sustainable PV solar utility model. In Proceedings of the 2014 IEEE Global Humanitarian Technology Conference (GHTC), San Jose, CA, USA, 10-13 October 2014; pp. 106-114.

16. IEEE Smart Village, Frequently Asked Questions. Available online: http://ieee-smart-village.org/resources / faq/ (accessed on 1 October 2015).

17. Koutroulis, E.; Kolokotsa, D.; Potirakis, A; Kalaitzakis, K. Methodology for optimal sizing of stand-alone photovoltaic/wind-generator systems using genetic algorithms. Sol. Energy 2006, 80, 1072-1088.

18. Ashok, S. Optimised model for community-based hybrid energy system. Renew. Energy 2007, 32, $1155-1164$.

19. Yang, H.; Zhou, W.; Lu, L.; Fang, Z. Optimal sizing method for stand-alone hybrid solar-wind system with LPSP technology by using genetic algorithm. Sol. Energy 2008, 82, 354-367. 
20. Kanase-Patil, A.B.; Saini, R.P.; Sharma, M.P. Integrated renewable energy systems for off grid rural electrification of remote area. Renew. Energy 2010, 35, 1342-1349.

21. Ahlborg, H. Electricity for Better Lives in Rural Tanzania and Mozambique. Ph.D. Thesis, Chalmers University of Technology, Göteborg, Sweden, 2012.

22. Agarwal, N.; Kumar, A. Optimization of grid independent hybrid PV-diesel-battery system for power generation in remote villages of Uttar Pradesh, India. Energy Sustain. Dev. 2013, 17, 210-219.

23. Ramoji, S.K.; Kumar, B.J. Optimal economical sizing of a PV-wind hybrid energy system using genetic algorithm and teaching learning based optimization. Int. J. Adv. Res. Electr. Electron. Instrum. Eng. 2014, 3, 7352-7367.

24. Ko, M.J.; Yong, S.K.; Min, H.C.; Hung, C.J. Multi-objective optimization design for a hybrid energy system using the genetic algorithm. Energies 2015, 8, 2924-2949.

25. Barman, M.; Mahapatra, S.; Palit, D.; Chaudhury, M.K. Performance and impact evaluation of solar home lighting systems on the rural livelihood in Assam, India. Energy Sustain. Dev. 2017, 38, 10-20.

26. Maheshwari, Z.; Ramakumar, R. Smart Integrated Renewable Energy System (SIRES) for Rural Communities. In Proceedings of the 2016 Power and Energy Society General Meeting (PESGM), Boston, MA, USA, 17-21 July 2016.

27. Brown, N.L.; Tata, P.B.S. Biomethanation. In Bioenergy; International Development Research Centre: Ottawa, ON, Canada, 1990; pp. 111-117.

28. Fan, L.; Li, G.; Wang, F.; Geissen, V.; Ritsema, C.J. Factors Affecting Domestic Water Consumption in Rural Households upon Access to Improved Water Supply: Insights from the Wei River Basin, China. PLoS ONE 2013, 8, e71977.

29. Bassam, E.; Maegaard, P. Integrated Renewable Energy for Rural Communities; Elseveir Publication: Amsterdam, The Netherlands, 2004; pp. 10-11.

30. Longe, O.M.; Ouahada, K.; Ferreira, H.C.; Chinnappen, S. Renewable Energy Sources microgrid design for rural area in South Africa. In Proceedings of the 2014 IEEE PES Innovative Smart Grid Technologies Conference (ISGT), Washington, DC, USA, 19-22 February 2014; pp. 1-5.

31. Fraenkel, P.L. Water Lifting Devices; Food and Agriculture Organization of the United Nations: Rome, Italy, 1986; pp. 31-32.

32. U.S. Climate Data. Available online: http://usclimatedata.com/climate/stillwater/oklahoma/unitedstates/usok0507 (accessed on 20 September 2015).

33. Caslin, B. Potential of Farm Scale AD in Ireland; Agriculture and Food Development Authority: Carlow, Ireland, 2009.

34. Zhang, Y.; Kang, L.; Cao, B.; Huang, C.; Wu, G. Simulation of biogas generation. In Proceedings of the 2009 Transmission \& Distribution Conference \& Exposition: Asia and Pacific, Seoul, Korea, 26-30 October 2009; pp. 1-5.

35. Lotfi, S.; Tarazouei, F.L.; Ghiamy, M. Optimal Design of a hybrid Solar-Wind-Diesel Power System for Rural Electrification using Imperialist Competitive Algorithm. Int. J. Renew. Energy Res. 2013, 3, 403-411.

36. Mathew, S.; Pandey, K.P. Modelling the integrated output of wind-driven roto-dynamic pumps. Renew. Energy 2003, 28, 1143-1155.

37. Helmy, E.G.; Safya, M.E. Using Photovoltaic Array for Solar Water Pumping in Toshka Region, Egypt. In Proceedings of the 15th International Water Technology Conference, Alexandria, Egypt, 31 March2 April 2011.

38. Abdullah, K.; Coit, D.W.; Smith, A.E. Multi-Objective Optimization Using Genetic Algorithms: A Tutorial. Reliab. Eng. Syst. Saf. 2006, 91, 992-1007.

39. Taylor, M.; Daniel, K.; Ilas, A.; Young, E. Renewable Power Generation Costs in 2014; International Renewable Energy Agency (IRENA): Abu Dhabi, United Arab Emirates, 2015.

40. Purohit, P. Financial evaluation of renewable energy technologies for irrigation water pumping in India. Energy Policy 2006, 35, 3134-3144.

41. Paulsen, J.; Reynolds, T. Alternative Energy Pumps to Irrigate Smallholder Farmers' Land: What Is the State of the Art? Evans School Policy Analysis and Research: Seattle, WA, USA, 2010.

42. Kossmann, W.; Ponitz, U.; Habermehl, S.; Hörz, T.; Krämer, P.; Klingler, B.; Kellner, C.; Wittur, T.; von Klopotek, F.; Krieg, A.; et al. Biogas Digest: Biogas-Costs and Benefits. Inf. Advis. Serv. Appropr. Technol. $1999,3,10-11$. 
43. ALTE Polycrystalline Photovoltaic Module. Available online: https://www.altestore.com/static/datafiles/ Others / ALT100-24P_alte-solar-modules-spec-sheet.pdf (accessed on 5 January 2016).

44. Bergey Excel $1 \mathrm{~kW}$ Wind Turbine. Available online: http://bergey.com/products/wind-turbines/bergeyexcel-1 (accessed on 5 January 2016).

45. Solar Powered Water Surface Pumps. Available online: https://www.altestore.com/store/solar-waterpumps/surface-solar-pumps/suncentric-centrifugal-pump/dankoff-suncentric-7521-dc-surface-pumpp392/ (accessed on 5 January 2016).

46. Wind Mechanical Water Pumps. Available online: http://www.ironmanwindmill.com/pumping-capacity. htm (accessed on 6 January 2016).

47. Lambert, T.; Gilman, P.; Lilienthal, P. Micropower System Modeling with HOMER; National Renewable Energy Laboratory: Golden, CO, USA, 2006; pp. 415-416.

48. HOMER Energy Support. Total Net Present Cost in HOMER. Available online: http://usersupport. homerenergy.com/customer/en/portal/articles/2187252-total-net-present-cost-in-homer (accessed on 22 July 2017).

49. Basu, A.K.; Chowdhury, S.; Chowdhury, S.P. Value-Based Operational Strategy of CHP-Based Microgrid: A Comparative Analysis. In Proceedings of the 2010 45th International Universities Power Engineering Conference (UPEC), Cardiff, UK, 31 August-3 September 2010; pp. 1-5.

50. Dutt, G.S.; Ravindranath, N.H. Bioenergy: Direct Applications in Cooking. In Renewable Energy: Sources of Fuels and Electricity; Owino, F., Desai, A., Eds.; Wiley Eastern Limited: Maharashtra, India, 1993; pp. 676-677.

(C) 2017 by the authors. Licensee MDPI, Basel, Switzerland. This article is an open access article distributed under the terms and conditions of the Creative Commons Attribution (CC BY) license (http://creativecommons.org/licenses/by/4.0/). 